\title{
Strategies for Ideological and Political Education in Colleges from the Perspective of New Media
}

\author{
Liu Guoping ${ }^{1}$, Yang Xianzhi ${ }^{2}$ \\ ${ }^{1}$ Jingxi College of Application Science and Technology, Nanchang, China \\ ${ }^{2}$ Jiangxi College of Application Science and Technology, Nanchang, China
}

Keywords: new media era; innovation; ideological and political education; strategy

\begin{abstract}
The arrival of the new media era has brought new opportunities for the development of college students' Ideological and political education, and also brought serious and complicated challenges. To innovate the ideological and political education work in colleges and universities, it is necessary to grasp the principles of innovation, strengthen the construction of the team, take the initiative to occupy the highland of the new media, carry forward the main melody, spread the positive energy and enhance the effectiveness of the ideological and political education in colleges and universities.
\end{abstract}

With the rapid development of science and technology in the world, the information technology represented by Internet technology is increasingly affecting people's living habits, and profoundly changing people's way of existence and thinking. The arrival of the new media era has brought new opportunities for the development of college students' ideological and political education in innovative ways, and also brought serious and complicated challenges. Under the environment of the new media age, how to use the new media to carry out the ideological and political education of college students has become a new topic for the ideological and political education workers of college students.

\section{First. The characteristics of college students' communication environment in the new media age}

The new media era is the inevitable result of the rapid development of science and technology. In the traditional media era, newspapers, radio, television, magazines and other media are used as the carriers of communication. Mobile TV, touch screen media, digital cinema, 3D movie, digital magazine, digital broadcasting and other new medias, in the new media era are mainly relying on the use of Internet technology, cellular mobile communication technology and the students as the carriers of information. It constantly affects people's habits and ways of thinking, changing people's mode of production and lifestyle, and pushing forward the progress of human society. In the new media era, the communication environment among university students has the following characteristics:

(1) The virtual nature of the communication space;

(2) The openness of information dissemination;

(3) The equality of communication status;

(4) The diversity of information receiving.

\section{Second. Opportunities and Challenges of Innovating Ideological and Political Education in Colleges in the New Media Era}

Young students are the main forces in the new media age, and also the most direct and most influential people. In the era of digital technology, the understanding and attitude to the new media, the selection and contact of the new media and the screening and judgment of the content of the new media are directly related to the all-round development and the physical and mental health of 
the college students. The development of new media brings new opportunities for ideological and political education.

\subsection{The rapid development of information technology has brought new opportunities for promoting the construction of ideological and political education network classroom.}

As a useful supplement to the first class teaching, network classroom teaching has broken the limitations of time, space and selection. It also provides a more efficient and convenient learning platform for college students relying on the rich, shared and open network resources, which is increasingly popular with students. Through the network teaching platform, students can easily obtain the views of teachers and experts and scholars from different colleges, different regions and levels, increase knowledge, broaden their horizons, and deepen the understanding and mastery of theoretical knowledge, it effectively overcomes the limitations of the traditional single teaching mode. With the development of modern information technology, especially the gradual maturity of 4G network communication technology in China, it will greatly improve the speed of network information transmission, which provides an advanced platform for educators with rich resources. At the same time, ideological and political educators can communicate with college students, extend the time and space of education, and improve the efficiency and scope of ideological and political education.

\subsection{The new media has enriched the carrier of ideological and political education.}

As a new information communication tool and carrier, the new media, represented by Internet and mobile phone, has the characteristics of large information, wide coverage, strong interaction and quick convenience, which is far greater than any kind of transmission carrier in the traditional media era.

Computer and mobile Internet access has become one of the main ways for university students to access information and exchange ideas. With the help of new media, its advantages in combination with all kinds of network tools can be fully utilized, and a horizontal and vertical carrier of series of ideological and political education is built. Ideological and political educators should be good at using this position, through E-mail, QQ, WeChat and other network carriers, and students carry out one to one personalized ideological exchange, so that ideological and political education work more close to students, as well as the reality. Through an equal and interactive discussion, the communication barrier and communication pressure between students and teachers can be eliminated. Both sides can be honest and equal in debating, communicating, discussing, promoting consensus and narrowing differences. At the same time, micro-blog, WeChat group, QQ group and other ways are used to spread and radiate the theoretical points of ideological and political education to students in more than one form, and through comments and discussions and so on, the students are imperceptibly influenced, and the confusion and doubt in the process of students' growth are eliminated in time.

\subsection{The rich information of new media broadens the vision of ideological and political education in colleges.}

The new media has many advantages, such as huge information capacity, rich resources, rapid information dissemination, quick information dissemination, quick and convenient search, wide coverage. It reduces the tediousness of teachers' frequent search for information in the library. It can provide rich teaching materials for teachers, enriching the content of classroom teaching and supplementation. The teaching cases close to students' life have improved the interest, pertinence and permeability of teaching. At the same time, students can quickly and easily understand the world, news and information, cutting-edge science and technology and theoretical knowledge through various new media platforms so as to broaden their horizons, cultivate sentiments, perfect knowledge structure and enhance connotation and culture. The correct and full use and control of the new media platform's advantages and characteristics, and the development of ideological and political education with diverse forms, will undoubtedly greatly improve the radiation, attraction of ideological and political education, and promote the modernization of ideological and political 
education.

\subsection{Challenges to ideological and political education in the new media era.}

Although the advent of the new media era has added a new carrier to the ideological and political education work, the new media is also a "double-edged sword", which has also brought great challenges to work. But in the new media era, the convenience of information release makes all sorts of good and bad information pour into people's vision, especially the hostile forces are constantly using the new media platform to disseminate their ideology, strengthen cultural expansion and ideological penetration for young students, plus social negative corruption and society. The impact of contradictions on socialist value system has greatly weakened the credibility of social belief propagation and increased the difficulty of ideological and political education. In addition, the increasingly strong business atmosphere is affecting the new media environment, pornography, violence, online games, increasingly impacting the students' normal learning and life, and bringing new impact on their personality, moral concept, value orientation and so on. Furthermore, as the mental development is not mature, the ability of analyzing and understanding things is weak, and the resistance to Internet temptation is poor. It is easy to indulge in online games and network pornography, find pleasure in the illusory world, disuse school and overdraw the youth. In the face of these severe challenges, it is urgent for the ideological and political education workers of colleges to innovate work ideas and to strengthen the innovation of ideological and political education in the new media era.

\section{Third. The principles of Innovating Ideological and political work in colleges in the New Media Age}

(1) Firmly grasp the socialist ideological position. In the new situation of the increasingly frequent exchanges of ideological and cultural exchanges in the world, the use of new media technology to spread ideology is not only an important task of Marx's doctrine, but also the main work of all kinds of hostile forces. At present, the new media, such as Internet and mobile phone, has exerted more and more influence on college students. All kinds of bad social thoughts have had a profound influence on the world outlook, outlook on life and values of college students. Some college students have the confusion of political belief, the fuzzy ideal belief, the distortion of the value orientation and the lack of social responsibility. This situation urgently to be solved by taking the initiative to occupy the new media position with the socialist core value system, strengthening the education of students with patriotism, collectivism and socialism, and adhering to the "establishment of a sound moral system to establish a sound personality" as the fundamental task of ideological and political education for college students in contemporary colleges as the promotion of the ideological and political education. The urgent need for the development of socialism with Chinese characteristics is a necessary means to guide the healthy growth of college students and scientific accomplishment.

(2) Adhere to the principle of combination of initiative inculcation and interaction. Active inculcation has long been a fundamental tool for our ideological and political education. Relying on the mainstream media, classroom teaching and sports activities, we have strengthened the Marx's ideological education and indoctrination of college students, and achieved positive results. In the new media era, multiple open channels and ways of communication have brought a new impact on a single way of education. It is urgent for us to innovate ways and methods, to actively use new media to carry out work, to inculcate as an interactive communication, to respect students' main position and to integrate into the students' thoughts and inner world. In the process of equal communication with them, the correct values are permeated into the minds of students, imperceptibly affecting them to establish the correct values.

(3) Adhere to the principle of combining advantage and effective integration. In order to carry out the work of ideological and political education, it is important to keep pace with the times, grasp the new knowledge and technology needed in the new media era, and innovate methods and means. It is necessary to not only maintain the traditional advantages of the previous ideological and 
political work, but also use the traditional means to make the thought of political work scientific, standardized and established. Taking advantage of the new media in the new media era, the ideological and political work should be integrated with the new media, their respective advantages should be given full play, and the sustainable development of Ideological and political education should be promoted.

(4) Adhere to the principle of combining reality with virtual control. Over many years, there have been a lot of successful experiences in ideological and political education in China, and a set of effective methods to carry out ideological and political education in real life has been summed up in practice. To carry out ideological and political work in the real society, it must conform to the objectivity and reality principle of things. Only when ideological and political education workers grasp the ideological thread of students can they have a better educational effect. In the new media era, the network creates a virtual space for students with both charm and vitality. They have become the masters of this space. This requires to explore and control the space, make full use of the virtual space to make up for the shortage of real life, become the students' friends as soon as possible, and consider from their perspective. The idea and behavior are given correct guidance and necessary encouragement to combine the ideological political education work between the lines and promote the full integration of reality and virtuality.

\section{Fourth, Innovate the Strategy of Ideological and Political Education in Colleges in the New Media Age}

"The Internet has become a distributing center of ideological and cultural information and the amplifier of public opinion. It is important to fully understand the social influence of the emerging media represented by the Internet, and attach great importance to the construction, application and management of the Internet." Comrade Hu Jintao stressed in the work of the people's daily. In view of the environmental changes in the new media era, it is a realistic problem that colleges must face the innovation of the ideology and political education in colleges and improve the effectiveness of ideological and political education.

(1) Take the initiative to occupy the propaganda heights under the new media era, and unswervingly use the socialist core value system to arm young students' minds. The socialist core value system is a major theoretical innovation and breakthrough in the ideological and cultural construction of the Communist Party of China after persisting in keeping pace with the times. This is the essence of China's advanced socialist culture. Under the social background of today's political multi-polarization and value pluralism, the socialist core value system is persistently used to guide ideological and political education. This is also the political responsibility and historical mission of ideological and political education workers. In the new media era, the spread of various non Marx and anti- Marx comments on the new media carrier is becoming more and more difficult to control the position of public opinion in the new media. Under such a new situation, colleges should attach great importance to the role of new media.

(2) Actively control the new media position and create a healthy and upstart campus new media culture. Through the new media position, it is necessary to not only spread theoretical knowledge to students, but also transmit cultural values to students. WeChat, QQ, micro-blog and other platforms should be fully used to vigorously promote the outstanding teachers and students' typical deeds, good people, moral models, learning standards, school development and construction achievements, and the achievements of the construction of the school style. It is equally important to enhance the enthusiasm and passion of students to love the school, carry forward the main theme and spread positive energy.

(3) Enhance the ideological and political education workers' new media literacy and create a professional, professional and expert teaching staff. In the new media environment, educators should take the initiative to strengthen the understanding and mastery of the new media, disseminate correct ideas, values and feelings of life among students, and strive to make college students the masters of the new media carrier. In view of the social hot spots, ideological burdens, misgivings, employment guidance and other issues of college students' attention, the students are 
encouraged to exchange and interact with their peers, and students are widely invited to join the discussion, allowing them to publish different views, pay attention to the guidance, inspiration and penetration of students' words and deeds, avoiding preaching, criticism and sarcasm, and learning from each other. In the process of student interaction, the dissemination and infiltration of the socialist core value system should be carried out imperceptibly so as to enhance the effectiveness of education.

\section{References}

[1] HETING SUN. Analysis of Ideological and Political Education in Colleges and Universities based on "Micro-Platform" [A]. Wuhan Zhicheng Times Cultural Development Co., Ltd. Proceedings of the 2017 International Conference on Arts and Design, Education and Social Sciences(ADESS 2017)[C].Wuhan Zhicheng Times Cultural Development Co.,Ltd:,2017:7.

[2] Yu Liu. Research on the Innovation of Ideological and Political Education of Colleges and Universities at Micro-times [A]. Institute of Management Science and Industrial Engineering. Proceedings of 2017 International Conference on Advanced Education, Psychology an d Sports Science (AEPSS 2017)[C].Institute of Management Science and Industrial Engineering:,2017:5.

[3] Yuxia Ding. On the Integration of Socialist Core Values into Ideological and Political Education in Colleges and Universities [A]. Research Institute of Management Science and Industrial Engineering. Proceedings of 2017 4th International Conference on Education, Management and Computing Technology (ICEMCT 2017)[C].Research Institute of Management Science and Industrial Engineering:,2017:5.

[4] Zhichao Li. Research on Brand Communication of Ideological and Political Education in Colleges and Universities [A]. Singapore Management and Sports Science Institute, Singapore. Proceedings of 2015 SSR International Conference on Social Sciences and Information (SSR-SSI 2015 V11) [C].Singapore Management and Sports Science Institute,Singapore:,2015:6. 